\title{
Urban Iowa \\ One Hundred Years Ago
}

\author{
LAWRENCE H. LARSEN
}

IN 1880 the predominately rural state of lowa had an urban dimension. The census that year showed that 126,227 of the Hawkeye state's 1.6 million inhabitants lived in cities of ten thousand or more persons-the breaking point used by nineteenth-century demographers to differentiate between large and small cities. Of the 227 such localities in the United States, lowa contained only seven, and none exceeded twentyfive thousand persons. Spread across the state, they included Dubuque $(22,254)$, Davenport $(21,831)$, Burlington $(19,450)$, and Keokuk (12,117), all on the Mississippi River; Cedar Rapids $(10,104)$ on the Cedar River; Des Moines $(22,408)$ at the confluence of the Des Moines and Raccoon rivers; and Council Bluffs $(18,063)$ on the Missouri River. ${ }^{1}$ None of the cities even remotely approached the status of a "Great City" (a metropolis of one hundred thousand or more), twenty of which existed in the nation in 1880. Yet the Hawkeye state communities were far from

In much different form this article was presented at the Twenty-first Annual Northern Great Plains History Conference in Eau Claire, Wisconsin, in September 1986. The author gratefully acknowledges the comments of Dana Miller of the Iron Range Research Center.

1. Valuable data on the rise of urban Iowa can be found in George E. Waring, Jr., comp., "The Southern and Western States," Report on the Social Statistics of Cities, Tenth Census of the United States, 1880, vol. 19, pt. 2 (Washington, D.C., 1886), 2: 730 (Dubuque), 719-20 (Davenport), 707 (Burlington), 734 (Keokuk), 720 (Cedar Rapids), 725-26 (Des Moines), 715 (Council Bluffs). Hereinafter cited as Social Statistics of Cities. This magnificent compilation, containing primary data collected by thousands of people, also profiles urban services. Robert P. Porter, The West: From the Census of 1880, a History of the Industrial, Commercial, Social, and Political Development of the States and Territories of the West from 1800 to 1880 (Chicago, 1882), 543, has urban economic material. An overview of settlement patterns can be found in William J. Petersen, "Population Advance to the Upper Mississippi Valley, 1830-1860," Iowa Journal of History and Politics 32 (October 1934), 312-53. 
being insignificant backwaters. Rather, they functioned as important components of an emerging midwestern urban system. Corn, for example, flowed through them and on to Chicago for shipment either via the Great Lakes or by rail to the eastern seaboard for eventual shipment overseas.

Much of the shaping of the American urban network in the nineteenth century occurred after the official frontier line had passed through an area. Chicago was removed from the edge of settlement when it won a vast commercial empire; Kansas City, in its early days little more than a glorified trading camp, only emerged as a regional metropolis after the Civil War. The Iowa cities were no exceptions, achieving their significant urban dimensions after the official end of the pioneering period in the state in 1870 .

The arrival of railroads played crucial roles in building up Des Moines and Council Bluffs. The national railroad age had started in the 1850s, following three decades of major advances in technology, including the perfection of the telegraph and advances in the construction of bridges. These and other developments made it possible to build large regional rail systems and to create a railroad network that extended throughout the land. Although being on a railroad did not automatically ensure great success - the Iowa communities of Agency, Elvira, and Yorktown serving as cases in point-no place in Gilded Age America could prosper and advance without one.

In 1880 the seven Iowa cities were at a typical post-frontier stage of development. They exhibited all the hallmarks of nascent urbanism: significant population concentrations, institutionalized governments, attempts to provide services, and plans for economic diversity. In these and other matters, urban Iowa mirrored older established urban areas. As far as practical, the pioneers of urban Iowa tried to construct cities in the image of what they knew "back east." Since no place planned to fail, the goal was to copy on a smaller scale what had been done in such cities as New York, Boston, and Philadelphia. Thus, for example, most street plans were grids, and police and fire departments were smaller versions of those in the big cities.

Yet subtle modifications helped to bring about gradual changes from the older forms. Iowa planners tended to provide for courthouse squares and to lay out important streets running 


\section{Urban Iowa}

directly away from rivers rather than parallel to them. ${ }^{2}$ Police, who did not have to worry about concentrating on high crime districts, like those common to most seaports, tried new tactics; and firemen did not need the same kind of equipment necessary to cope with blazes in large buildings located in congested areas. Iowa cities also quickly adopted technological innovations. A Des Moines resident recalled the first electric arch light switched on in "its blue-white glory" in 1881 at a local drug store: "Snowflakes were falling softly as we stood admiring that great sight-a light so powerful one could read the Register or the Leader with ease from across the street." Not to be outdone, Council Bluffs had a telephone system in 1879 , only three years after Alexander Graham Bell's invention. ${ }^{3}$ Still, on balance, young growing places sought to emulate old ones, sometimes deliberately and sometimes less so. In this sense, the Iowa cities were much like teenagers - they wanted to break away and do new things but most often found themselves bound by traditional values. Of course, the cities also developed distinctive personalities as they aged.

THE SEVEN IOWA CITIES with more than ten thousand residents in 1880 already displayed attributes that made them something special in the Hawkeye state. All of them were more cosmopolitan than the state at large. Fifteen percent of all Iowans were foreign-born, but the totals for the cities ranged from 19 percent in both Keokuk and Des Moines to 32 percent in Davenport. ${ }^{4}$ Generally, the higher the immigrant population, the lower the black population-immigrants tended to drive out

2. See Loren N. Horton, "Town Planning, Growth and Architecture in Selected Mississippi River Towns of Iowa, 1833-1860" (Ph.D. diss., University of Iowa, 1975); John W. Reps, The Making of Urban America (Princeton, 1965).

3. Thomas F. Drummond, "Des Moines 70 Years Ago," Annals of lowa 31 (October 1952), 466; Genevieve Powlison Mauck,"The Council Bluffs Story Through the Nonpareil's Eyes," Palimpsest 42 (September 1961), 425.

4. The foreign-born population of the other cities was Council Bluffs, 20 percent; Cedar Rapids, 22 percent; Burlington, 25 percent; and Dubuque, 28 percent. Table IX, "Population, as Native and Foreign-born, of Cities and Towns of 4,000 Inhabitants and Upward: 1880 and 1870," Statistics of the Population of the United States, Tenth Census of the United States, 1880, vol. 1 (Washington, D.C., 1883), 449; Table XVI, "Foreign-born population of Fifty Principal Cities, Distributed According to Place of Birth, Among the Various Foreign Countries," ibid., 538-39. 
blacks at the lower rungs of the job ladder. Keokuk had 1,081 blacks, representing 9 percent of all residents; blacks represented no more than 3 percent of the population of any of Iowa's other cities. ${ }^{5}$ Aggregations of females in the Iowa cities varied between 49 percent and 52 percent, except in Council Bluffs, where women accounted for only 44 percent of all residents. ${ }^{6}$ The low percentage was characteristic of places only recently removed from frontier days; the vanguard of settlers in a new region were usually men in their twenties and thirties. "Respectable" women followed, but it usually took several decades before the percentages evened out. More significant in a demographic sense, in urban Iowa native-born whites of both sexes remained in ascendancy. According to Governor William $\mathrm{H}$. Larrabee, certain elements were unwanted. In an 1885 immigration report he said that while the state was "ready to welcome to her soil the frugal, industrious, healthful family," it had no room "for the shiftless and indolent pauper."7

Although the population of Iowa's cities was more cosmopolitan than the rest of the state, urban Iowa was much less ethnic than many growing eastern industrial areas. The state's Gilded Age cities simply did not need a large influx of factory workers from overseas who would create overnight what authorities called "Zebra Striped" ethnic neighborhoods. Rather, the Iowa cities reflected the "old" immigration trends of the 1830 s and 1840s: Irish refugees from the potato famine and south German victims of agricultural displacement. If Iowa's industrial development had been different, say, similar to that in Wisconsin and Michigan, where the availability of raw materials led to post-Civil War booms in heavy industry, its urban ethnic mix probably would have been considerably more diverse, reflecting the immigration trends of the times.

5. Des Moines and Council Bluffs were 3 percent black; Cedar Rapids and Burlington, 2 percent; Davenport, 1 percent; and Dubuque, 0.65 percent. Table IV, "Population, by Race, of Cities and Towns of 4,000 Inhabitants and Upward: 1880 and $1870, "$ ibid.

6. Social Statistics of Cities, 2: 707 (Burlington), 712 (Cedar Rapids), 715 (Council Bluffs), 719 (Davenport), 725 (Des Moines), 730 (Dubuque), 734 (Keokuk).

7. Quoted in Mary K. Fredericksen, "The State of the State: Iowa in 1885," Palimpsest 65 (January/February 1984), 6-7. 
Other aspects of the urban condition distinguished the cities of lowa from the rest of the state. Three of the towns ranked among the top one hundred American manufacturing centers: Dubuque was seventieth in value of manufacturing products, Davenport eighty-fifth, and Des Moines ninety-fifth. Lumbering led in Davenport, printing in Des Moines, and carriage production in Dubuque. None of these industries generated products worth more than one million dollars annually. As Robert Porter, an authority on the 1880 census, explained about the Hawkeye state, "Its great boundary rivers are not trained to turn factory wheels yet, except at rapids." 8 But lowa had the potential in 1880 to become a significant manufacturing state.

Religion was another matter that set the cities apart. Statistics from 1890 showed that in predominately Protestant Iowa Roman Catholics constituted the largest single denomination in three of the cities: in Dubuque they made up 34 percent of the total population, in Davenport 15 percent, and in Des Moines 9 percent. The only significant Jewish congregations in Iowa were in Des Moines (414 members) and Davenport (50 members); there were no other synagogues in the state. ${ }^{9}$

Urban Iowa also contained the seven largest public school systems in Iowa, with yearly budgets ranging from $\$ 55,300$ in Des Moines to $\$ 34,700$ in Keokuk. In contrast to rural one-room schools, the urban districts had more subject diversification, even though they still emphasized the "three R's." Dubuque students, for instance, had the option of following classical, Latinscientific, or business tracks. ${ }^{10}$

Cultural, artistic, and architectural activities found what most observers considered their greatest expression in the cities of Iowa. In a popular vein, daily newspapers, including the

8. Table VI, “Manufactures of 100 Principle Cities, by Totals: 1880." Report of the Manufactures of the United States, Tenth Census of the United States, 1880, vol. 2 (Washington, D.C., 1883), xiii-xiv; Porter, The West: From the Census of 1880,544 .

9. Report on the Statistics of Churches in the United States, Eleventh Census of the United States, 1890, vol. 3 (Washington, D.C., 1894), xvii-xviii, 9195, 112-15. See Charles F. Griffith, "The Erection of the Diocese of Davenport," Mid-America: An Historical Review 30 (October 1948), 219-32.

10. U.S. Department of the Interior, Report of the Commissioner of Education: 1880, Report of the Secretary of the Interior, vol. 3 (Washington, D.C., 1882), 88-97. 
Burlington Hawkeye, the Des.Moines Iowa State Register, and the Council Bluffs Nonpareil strongly supported local business interests, promoted community betterment, and provided a sense of civic purpose and direction. Successful publishers promoted growth on the assumption that it was good for their own business interests. The newspapers' roles and contributions were obvious, but in most cases those of practitioners of the fine arts were hardly visible. What Iowa artists considered landmark events-an 1867 exhibition of paintings with an accompanying lecture series sponsored by the small Davenport Academy of Science, for example-indicated the scope of art appreciation in the state. As for architecture, the imposing gray stone state capitol building in Des Moines, constructed between 1871 and 1884, seemed to epitomize building design tastes in the Hawkeye state with its eclectic design and massive proportions. Many of the Iowa cities had large theaters: Green's Opera House in Cedar Rapids claimed 2,000 seats and the Opera House in Burlington held as many as 1,800 customers. Iowans, like other Americans, enjoyed a good show. Minstrels, singers, acrobats, vaudeville troops, stock companies, and Shakespearean actors all played urban Iowa. ${ }^{11}$ In many ways, the cities were crucibles of modern civilization in the predominately rural Hawkeye state.

\section{URBAN CONDITIONS may have distinguished Iowa cities} from the rest of the Hawkeye state, but on the surface at least they were much like medium-sized cities in other parts of the United States. Despite regional variations-obviously, architectural requirements were different in Savannah than in Cedar Rapids-there was a sameness about much of urban America. This seemed especially true of Gilded Age cities. After a period of frenzied speculation and construction throughout much of the country, the 1880 s became a time of restraint, a time to take stock and to determine what to do next. Hence, technical housekeeping aspects of city building loomed large on urban agendas. All places wanted to avoid appearing backward (a modern

11. Federal Writers' Project of the Works Progress Administration for the State of Iowa, Iowa: A Guide to the Hawkeye State, American Guide Series (New York, 1938), 124-28, 140-41, 155-62; Social Statistics of Cities, 2: 709 (Burlington), 713 (Cedar Rapids), 717 (Council Bluffs), 721-22 (Davenport), 727 (Des Moines), 732 (Dubuque). 
waterworks with great pumps and a gravity distribution system seemed superior to rain-catching cisterns that attracted large numbers of green worms and other objectionable insects during the summer), but all but a few were under severe fiscal restraints imposed by the taxpayers. Spending the least possible money for the best possible services was a major goal. Thus, the cities seldom launched striking innovations. Rather, they sought to avoid risks while providing basic services comparable to other places.

To satisfy taxpayers' demands for fiscal restraint, the city governments in the seven Iowa cities were small and traditional in form. Every place had a mayor and council form of government. In standard American practice, all the elected officials served on a part-time basis. Even at a time when there were calls for increasing professionalization in city administrations, there was no indication in the 1880 s that at the turn of the century Des Moines reformers would receive credit for pioneering the city manager form of government in the United States. In general, the Gilded Age Iowa urban governments sought to give voters an impression of permanent austerity. Modest public facilities reflected such goals. Dubuque's city hall, valued at $\$ 50,000$, was the most costly in all of Iowa. The Des Moines city government rented council rooms; Keokuk's administration occupied a floor in the downtown Odd Fellows' Building. ${ }^{12}$

Fiscal restraint did not mean that the Iowa cities enjoyed freedom from debts or taxes. The highest tax rates per $\$ 100$ of assessed valuation were $\$ 5.18$ in Des Moines and $\$ 5.12$ in Burlington, placing both near the top in the nation. Three places-Dubuque, Keokuk, and Des Moines-had large per capita debts of twenty-five dollars or more. All of the lowa cities had an outstanding net indebtedness, ranging from Cedar Rapids's $\$ 40,900$ to Dubuque's $\$ 804,600 .{ }^{13}$ The totals reflected

12. Social Statistics of Cities, 2: 709 (Burlington), 713 (Cedar Rapids), 717 (Council Bluffs), 721 (Davenport), 727 (Des Moines), 732 (Dubuque), 730 (Keokuk). See Charles Zueblin, American Municipal Progress (New York, 1916); William Bennett Munro, Principles and Methods of Municipal Administration (New York, 1918).

13. Social Statistics of Cities, 2: 707 (Burlington), 715 (Council Bluffs), 713 (Davenport), 725 (Des Moines), 730 (Dubuque), 734 (Keokuk); William Bennett Munro, Municipal Government and Administration, 2 vols. (New York, 1923); Johnson Bingham, Des Moines, the Pioneer of Municipal Progress and 
both the needs and extravagances of Iowa urbanites of the 1850s and 1860s. The first generation of Iowa town builders had left the next with big obligations, especially for railroad proposals. So Hawkeye city governments were expected as a matter of course to provide excellent services for small expenditures.

The Gilded Age Iowa cities naturally tried not only to emulate but to improve on urban services in other parts of the country. John S. Ely, a longtime Cedar Rapids resident, believed that the first settlers in his city set important and lasting standards.

Following the usual trend of emigration westward from the eastern states along the same latitude, the first settlers in our city were largely of New England ancestry and brought with them the pronounced traits of the inhabitants of that section, intensity of purpose, thrift, devotion to family, and strict in their moral and religious observances. Also, they believed that education and public charitable institutions were fundamental to the government of a free people, therefore, it followed that these traits were implanted in our city in its very infancy, and to a very marked degree influenced its growth and prosperity. ${ }^{14}$

Any discernible improvements in the public sector were quite limited. In addition to inadequate welfare functions, which mainly encouraged any potential recipients deemed ablebodied to leave town or go to the local poor farm, the cities tried to keep the streets passable, gave lip-service to improving the quality of life by supporting the concept of parks, and provided a range of protective activities. Services that taxpayers declined to fund or did not have the resources to undertake came from private sources-expensive waterworks, street railroads, and lighting systems.

Reform in the Middle West, Together with the History of Polk County, Iowa, the Largest, Most Prosperous County in the State of Iowa, 2 vols. (Chicago, 1911).

14. John S. Ely, "Memories of Early Cedar Rapids," Annals of Iowa 36 (Winter 1962), 229. See Bayrd Still, "Patterns of Mid-Nineteenth Century Urbanization in the Middle West," Mississippi Valley Historical Review 28 (September 1941), 187-206. For information on urban elites see Timothy R. Mahoney, "Urban History in a Regional Context: River Towns on the Upper Mississippi, 1840-1860," Journal of American History 72 (September 1985), 318-39. 
Urbanization brought with it mounting sanitary problems. The most obvious one involved trying to keep the streets clean. This-hauling away filth-was one of the major functions of any Gilded Age urban government. Failure to do so could mean political ruin for incumbents, especially as a general acceptance of the "germ theory" of disease focused public attention on the problem. The past practice of paying little attention to sanitation in constructing streets complicated matters. Thoroughfares built with little or no consideration of drainage needs were potential quagmires. Unfortunately, rain water was only one of the problems faced by Iowa street departments. Cities had an average of one horse for every four residents, and in an eight-hour working day a thousand horses deposited approximately five hundred gallons of urine and ten tons of dung in the streets. ${ }^{15}$

Because of a combination of the inadequacy and expensiveness of available street-cleaning machines, cities throughout the country relied on manpower to clean streets, either employing sanitation workers or contracting with private scavengers. Under standard procedures, advance men swept street dirt into gutters, and following workers shoveled the smelly substances into carts for transportation to dump sites. Even the most diligent efforts failed to result in clean thoroughfares; no one found an effective way to scour streets in the "Horse Age."

The efforts undertaken in the Iowa cities reflected the realities of the period, with low levels of expenditures serving as one indication of the prevailing attitude that the problem had no practical solution. In Davenport, which spent all of five hundred dollars annually to clean only major streets, a bureaucrat admitted that "not enough street-cleaning is done." Des Moines attempted to scrub business streets monthly and all others as the need arose. "The system is not good," the supervisor said, "as it is mostly done by prisoners who don't like to work." Keokuk sanitation workers flushed the roadways whenever they felt conditions warranted. As might have been expected, this approach did not work out very well. "There is no system," a city employee reported, "the work being done very imperfectly and not as

15. Lawrence H. Larsen, "Nineteenth-Century Street Sanitation: A Study of Filth and Frustration," Wisconsin Magazine of History 52 (Spring 1969), 239-47; Joel Tarr, "Urban Pollution-Many Long years Ago," American Heritage 22 (October 1971), 65-69, 106. 
often as it should be."16 The casual methods explained why pedestrians wore high boots. People took filth for granted, and officials were under no special pressure to make improvements.

Street sweepings found a variety of different uses, none of which were part of a systematic scheme. Burlington had no special way of depositing sweepings beyond using some of the street dirt to correct street grades and fill potholes. In Cedar Rapids sanitation workers threw sweepings directly into the Cedar River. A Des Moines official curtly reported, "Places of deposit good enough, as it reclaims waste land." In Keokuk, according to a spokesperson, sweepings were "deposited anywhere that is convenient." ${ }^{17}$ Throughout urban Iowa, as in much of the rest of urban America, city governments ignored health authorities who cautioned against the indiscriminate disposal of unsavory substances, called "axle grease," which included a high volume of manure and urine.

The necessity of removing dead animals was a related problem. Cities tried to get by as cheaply as possible, sometimes selling carcasses to local manufacturing establishments. In Burlington, which spent two hundred dollars annually on the removal of dead animals, the city marshal was responsible for the task. Council Bluffs, Keokuk, and Davenport had no direct costs; workers in glue, fertilizer, and rendering plants claimed most animal bodies. Sometimes animal carcasses moldered for a long time, becoming offensive to both sight and smell before anything was done about them. A Council Bluffs official reported, "In case they become nuisances, the owner of the property on which they are found is obliged to bury them." In Des Moines the city marshal buried dead beasts. ${ }^{18}$ Not all of the deceased animals of urban Iowa ended up in factories or graves. Many rabbits, cats, dogs, and squirrels moldered where they expired, posing potential threats to human health.

16. Social Statistics of Cities, 2: 723 (Davenport), 728 (Des Moines), 737 (Keokuk). The quotes are from this source. See Lawrence H. Larsen, "Urban Services in Gilded Age Wisconsin," Wisconsin Magazine of History 71 (Winter 1987-88), 83-117.

17. Quoted in Social Statistics of Cities, 2: 710 (Burlington), 714 (Cedar Rapids), 728 (Des Moines), 737 (Keokuk).

18. lbid., 2: 710 (Burlington), 717 (Council Bluffs), 723 (Davenport), 728 (Des Moines), 737 (Keokuk). The quote is from this source. 
Garbage and ashes received a number of dispositions, most of which were imperfectly executed. Burlington had no regulations except for a nuisance ordinance. "It is reported," an administrator admitted, "that only the general habits of cleanliness of the people prevent serious results from the lack of system." In Cedar Rapids and Council Bluffs, householders had the job of hauling away their own garbage and ashes to undesignated locations. Des Moines had rigid rules requiring the burying of garbage and the disposal of ashes on designated waste lands. Apparently, few people complied with the measures. The mayor conceded, "The ordinance prohibiting people from depositing ashes, debris, and filth in the streets and alleys is entirely ignored, rendering it impossible at times to get through them with a loaded wagon, and seriously endangering the health of the citizens on the approach of warm weather." The situation appeared worse in Keokuk, where a city official admitted, "everyone does as they please." ${ }^{\prime 19}$ Throughout urban Iowa, authorities failed to collect garbage and ashes adequately. Solid wastes thrown into the streets and on to vacant lots added to general filthy conditions.

In 1880 the quickening national pace of sewer construction had hardly touched urban Iowa, despite incorrect conclusions by experts that a series of yellow fever epidemics in the South resulted from the indiscriminate disposal of human wastes. George Waring, Jr., a leading sanitary authority and a member of the prestigious federal National Board of Health, advocated "separate systems" of sewerage for ground runoff, household waste, and human excreta to ward off the threat of what he euphemistically called "sewer gas. ${ }^{20}$ Waring's assertion that incredibly filthy conditions in the sewerless city of Memphis caused an 1878 yellow fever epidemic that killed five thousand people probably contributed to urban Iowans' desire for comprehensive systems of sewerage. However, sewers not only led

19. Ibid., 2: 710 (Burlington), 714 (Cedar Rapids), 717 (Council Bluffs), 728 (Des Moines), 737 (Keokuk). The quotes are from this source. See Martin V. Melosi, Garbage in the Cities: Refuse, Reform, and the Environment, 1880-1980 (College Station, TX, 1981), 3-20.

20. See James W. Cassedy, "The Flamboyant Colonel Waring," Bulletin of the History of Medicine 36 (March-April 1962), 163-76. 
automatically to the pollution of streams and watering grounds, but represented very costly ventures.

No Iowa city had developed a comprehensive sewerage by 1880. In Cedar Rapids the city constructed sewers on a case by case basis, with property owners paying half the costs. Council Bluffs had only 1,600 linear feet of brick and wooden sewers, all of which emptied into sloughs along the Missouri River. Davenport and Des Moines had developed plans that were only partially carried out. Both places still contained old private lines and, in the case of Davenport, open surface gutters that carried sewage. In lieu of sewers a widespread use of cesspools and privies for human waste created health hazards. Between 85 and 90 percent of all Burlington and Cedar Rapids residents depended upon privy-vaults. In Council Bluffs old dry wells and cesspools received almost all of the night soil. Removal plans that looked good on paper, at best, did not work very well in practice. In Des Moines, for instance, an ordinance stipulated that licensed private scavengers clean privies only between 11 p.m. and $4 \mathrm{a} . \mathrm{m}$. This was all to the good, except that the scavengers threw the night soil directly into the Des Moines River, from which many places downstream drew their water supplies. Neither liquid industrial nor household wastes received much attention. Waste material in Council Bluffs and Davenport ran into porous cesspools; Keokuk had no regulations at all. ${ }^{21}$ While decaying filth and noxious odors represented one of the more unpleasant aspects of life in the Gilded Age, most people took the situation for granted.

In 1880 waterworks were in place in all the Iowa cities except Council Bluffs, where one was under construction. Because waterworks cost so much money, all the Hawkeye state facilities were owned by concerns that had gained monopolies from city governments. As might have been expected, the practice of putting such an important commodity as water in private hands caused controversy. In Burlington a long-running controversy resulted in the creation of a works financed from both public and private sources and the city had the option to buy it on one

21. Social Statistics of Cities, 2: 710 (Burlington), 714 (Cedar Rapids), 717 (Council Bluffs), 723 (Davenport), 728 (Des Moines), 737 (Keokuk). 
year's notice. ${ }^{22}$ The mayor of Burlington lamely explained, "The city practically owns the works, and the company operates them."

Waterworks were not only an expensive mark of prestige, but they represented major advances in nineteenth-century technology. The emphasis was on large machines capable of raising water to reservoirs and moving it through pipes to customers. Holly engines at Davenport pumped Mississippi River water directly into twenty-two miles of distributing mains. The end product, despite an optimistic evaluation, left much to be desired. "As the water supply of Davenport is drawn from the rapids, it is highly aerated, so much so as to be a milky color, and like soda-water when first drawn from the hydrants," a Davenport physician with promotional instincts explained, trying to put the best face on direct pumping. "This large mixture of atmospheric oxygen must have an important influence in destroying any organic matters, and hence add much to the wholesomeness of the water. ${ }^{23}$ Nevertheless, with good reason, most water takers boiled the water.

Health conditions were an increasing concern in the Iowa cities of the Gilded Age. At a time when constant fear of endemic diseases, especially typhoid, cholera, and smallpox, heightened community concerns, American political traditions complicated affairs, negating the formulation of a national public health policy. The National Board of Health of the 1880 s only lasted a few years, falling victim to jurisdictional disputes with other federal bodies, notably the Marine Hospital Service, and opposition from local and state boards of health. ${ }^{24}$ Iowa had basic sanitary laws that governed all the cities in the state. The state legislature forced an arbitrary bureaucratic health structure on cities: the mayor and aldermen of each incorporated community constituted a board of health which had the responsibility of appointing a "competent physician" as chief health officer; either the city clerk or recorder of deeds served as board secretary.

22. Willard Toussaint, "'The Fire Fiend Doffs his Hat': Burlington's First Water Works," Annals of Iowa 38 (Winter 1967), 510-26.

23. Social Statistics of Cities, 2: 721 (Davenport).

24. For a concise administrative history of the agency, see "Records of the National Board of Health, 1879-84," Guide to the National Archives of the United States (Washington, D.C., 1974), 503. 
Beyond that, municipalities were on their own; the state offered little other guidance and failed to appropriate any money to support operations.

Under the circumstances, city officers tried to spend as little as possible, to avoid imposing regulations, and to interpret the state statutes broadly. Some of their efforts were negligible. The Burlington city council claimed to conduct health business at its regular meetings, and only allowed the inspection of nuisances after receiving formal complaints. The board of health in Cedar Rapids investigated alleged health hazards and quarantined victims of contagious diseases. The monetary problems of the Keokuk Board of Health mirrored those of others in urban Iowa. According to a functionary, Keokuk's board had "general supervision over the health of the city, the cleanliness of streets, alleys, public places, lots, yards, etc.," plus various police powers. To perform these and other duties, the board had an annual budget of $\$ 150$, hardly enough to keep an office open. ${ }^{25}$ Of course, during epidemics the Keokuk board and all the others in urban Iowa had the authority to assume emergency powers and to spend-if the situation required-large amounts of money. Without an emergency, no one seemed to care much about health matters.

The Iowa cities of $\mathbf{1 8 8 0}$ took fire and police protection more seriously. Particularly in the case of fire protection, they did so for good reason. In the winter of 1854-55 a "great fire" had swept over Council Bluffs, destroying the entire upper part of the city. Burlington experienced serious fires in 1871 and again in 1873. No one wanted to have similar calamities happen again. Fresh in the memory of many lowans was the Chicago Fire of 1871 , which destroyed 18,000 buildings and left 160,000 people homeless. The burned-out Chicago residents numbered more than the inhabitants in all the cities of Iowa.

All the Hawkeye cities had professional fire departments. In 1878 Burlington spent $\$ 6,863.22$ on its force; the costs in Des Moines in 1880 amounted to $\$ 6,162.62$. For such costs, the citizenry received what appeared to be considerable fire protection. Burlington had eighteen professional firefighters, including the

25. Social Statistics of Cities, 2: 709-10 (Burlington), 714 (Cedar Rapids), 717 (Council Bluffs), 736 (Keokuk). 
chief. A rapid dispatch team of "minute men" remained constantly on duty, ready to swing into action whenever the telephone fire alarm rang. Available apparatus consisted of four hose carriages and one hook-and-ladder truck. Des Moines had twenty-six firemen who manned one steam fire engine, two hook-and-ladder trucks, and six hose carriages. In 1880 the Des Moines department only answered thirty-six alarms, one of which was false; their counterparts in Burlington responded to sixty-five alarms in $1878 .{ }^{26}$ Having a waterworks supposedly cut fire losses. The owner of the Burlington works, Charles Mason, observed after the quick dousing of a potentially serious blaze, "The fire fiend took off his hat and yielded the field to his acknowledged master. This is the third fire that has been squelched without making any progress. In each case the fire would have proved vitally destructive except for our works." ${ }^{27}$ Because any fire could have potentially devastating consequences, fire departments covered all parts of town. Although no city in the nation had the capability of defending itself against a gigantic conflagration, well-organized and efficient fire departments could contain most blazes and hold down damage.

Highly structured police departments-distinctive urban institutions - served as the bulwarks of protective services in the Gilded Age Iowa cities. ${ }^{28}$ Even though the police enjoyed considerable power in the performance of their duties, civilian authorities, in keeping with national patterns, had ultimate control over law enforcement agencies. In Burlington and Cedar Rapids the mayor appointed all the law enforcement personnel, and the city council confirmed the selections. Acting alone, the city council in Council Bluffs selected the police force. By national standards Iowa law officers made good annual salaries. A captain of police in the Davenport force made $\$ 720$; his counterpart in Des Moines earned $\$ 600$. Patrolmen in both Council Bluffs and Burlington were paid $\$ 480$; Davenport officers received between $\$ 480$ and $\$ 600$. As a result, many people coveted police

26. Ibid., 2: 711 (Burlington), 729 (Des Moines).

27. Quoted in Toussaint, "'The Fire Fiend Doffs his Hat," 524.

28. Social Statistics of Cities, 2: 711 (Burlington), 714 (Cedar Rapids), 718 (Council Bluffs), 723 (Davenport), 728-29 (Des Moines). All the police data is from this source. See also Raymond Fosdick, American Police Systems (New York, 1920). 
jobs, which usually were political appointments. All the police in urban Iowa wore uniforms as they tried to keep the peace. A Davenport official, reporting on police attire in his city, wrote, 'The uniform is what is known as the 'New York regulation,' and the city gives each man $\$ 5$ a month for his uniform and a chain 'come-along.' "29 Wearing a police uniform, which officers usually had to purchase themselves, entailed long hours of work. Burlington police served twelve hours per day and walked over six miles of streets; Cedar Rapids police each patrolled three-tofive mile beats during their twelve-hour shifts. Des Moines patrolmen, equipped with revolvers, clubs, and duplex whistles, worked from 6:00 a.m. to 6:00 p.m., and made 1,037 arrests in 1880 , primarily for drunkenness, assault and battery, larceny, disturbing the peace, and keeping houses of ill-fame. During the same year intoxication and assault and battery accounted for most of the 809 apprehensions in Burlington. All in all, organized police forces afforded urban residents a sense of security, helping to convince them that they could be defended effectively from criminal elements.

THE SEVEN CITIES with more than ten thousand residents in the predominately rural Hawkeye state in 1880 were harbingers of urban growth in the aftermath of the frontier. None of the towns alone was very important by national standards. In the Midwest such emerging great cities as Chicago in Illinois, Milwaukee in Wisconsin, Minneapolis-Saint Paul in Minnesota, Omaha in Nebraska, and Saint Louis and Kansas City in Missouri outstripped the Iowa cities. Of course, such hindsight observations did not represent the prevailing thinking of Gilded Age lowa urban leaders, or, for that matter, the vast majority of city residents. They saw Iowa urbanization in the context of the doctrine of progress and a national spirit that would lead automatically in the direction of future growth. Accordingly, Des Moines, Davenport, and the other Iowa towns would go on to achieve metropolitan status. So went the theoretical course of events.

In 1880 the lowa cities had achieved the kind of progress expected of American cities of the day. All the towns were in the mainstream of Gilded Age urban trends. Railroads and rivers,

29. Quoted in Social Statistics of Cities, 2: 723. 
plus, to a lesser extent, roads, contributed to the growth of cities. Ethnic and religious diversity was an accepted reality of the American experience. Most manufacturing had an agrarian base. Farming-perhaps more so than in neighboring statesformed the backbone of commercial urban business undertakings. At a time when the "lure of the city" attracted millions of people from home and abroad, the Hawkeye communities were the centers of cultural life in the state. All of them had public school systems. Literature, artistic pursuits, and architecture reflected the fruition of post-frontier Iowa life. In particular, the professionalization of government had followed traditional American lines, with its salient feature being a desire to hold down costs while improving services. This affected everything from the cleaning of streets to the disposal of garbage and ashes. Urban Iowans willingly waded through streets clogged with filth and risked epidemic diseases to avoid paying higher taxes, though threats to health did bring large expenditures for systems of sewerage. City dwellers relied on privately supported waterworks, lighting networks, street railroads, and, in some cases, sanitation scavengers. Out of immediate necessity, police and fire departments received more money than other services.

The Iowa cities were groping for adequate solutions to the kinds of problems automatically brought about by a transition from village to city. In the process, urban Iowans moved in the direction of becoming part of a nation of city people. A New York reporter who visited urban Iowa in 1878 emphasized the growth, prosperity, and enterprise abroad. Speaking of Des Moines, he said, "Energy and enterprise are visible on every street. It is no marvel that what has already been done is a matter of pride to every citizen or that their future aims are set high." ${ }^{30}$ Such high hopes and ambitions were characteristic of the urban parts of the Hawkeye state. Ultimately, though, Iowa's cities were destined to continue to function as complementary parts of a system whose major contribution to the nation was agriculture.

30. Quoted in Mauck, "The Council Bluffs Story," 247. See Lawrence H. Larsen, The Urban West at the End of the Frontier (Lawrence, KS, 1978). 
Copyright of Annals of Iowa is the property of State of Iowa, by \& through the State Historical Society of Iowa and its content may not be copied or emailed to multiple sites or posted to a listserv without the copyright holder's express written permission. However, users may print, download, or email articles for individual use. 